\title{
Interleukin 8 Measurement
}

National Cancer Institute

\section{Source}

National Cancer Institute. Interleukin 8 Measurement. NCI Thesaurus. Code C74836.

The determination of the amount of interleukin 8 present in a sample. 